\title{
THE GLOBAL RENT GAP OF LISBON'S HISTORIC CENTRE
}

\author{
IAGO LESTEGÁS ${ }^{1}$, RUBÉN-CAMILO LOIS-GONZÁLEZ² \& JOÃO SEIXAS ${ }^{3}$ \\ ${ }^{1}$ Institute for Studies and Development of Galicia, University of Santiago de Compostela, Spain. \\ ${ }^{2}$ Department of Geography, University of Santiago de Compostela, Spain. \\ ${ }^{3}$ Department of Geography and Regional Planning, New University of Lisbon, Portugal.
}

\begin{abstract}
This work deals with the ongoing commodification of Lisbon's historic centre under the pressure of mass tourism and transnational real estate investment. It applies a case-study research methodology combining the quantitative analysis of statistical data on relevant socioeconomic indicators with qualitative tools such as direct observation and structured interviews with key stakeholders. In the context of crisis and austerity, and taking into account the Portuguese financial dependency and peripherality within the Eurozone, this work argues that the rent gap triggering the current transformation of Lisbon's historic centre owes much to the global gap between purchasing powers on the internal and the external markets. With the former strangled by austerity policies that have impoverished the Portuguese society, the dramatic rise of housing prices in Lisbon's historic centre is a consequence of the expansion of demand on wealthier external markets, encouraged and guaranteed by an investor-friendly legal framework implemented in the context of the crisis. This policy set includes the new urban lease law, the non-regular resident tax regime, the Golden Visa programme, the special fiscal framework for the local accommodation business, and the tax breaks for real estate funds and refurbishment initiatives. Despite its undisputed success in bringing foreign investment and stimulating the rehabilitation of derelict properties in Lisbon's historic centre, this legal framework has triggered gentrification. Real estate prices are pushed above the financial capacity of most local households, and an enclave-type exploitation of the housing stock emerges in Lisbon's historic centre that jeopardizes the former's access to housing in that territory and in its immediate surroundings. However, grassroots movements and social initiatives advocating affordable housing and the right to the city have emerged in Lisbon.

Keywords: austerity, Eurozone, gentrification, housing, public policy, urban commodification.
\end{abstract}

\section{INTRODUCTION}

Lisbon's historic centre constitutes an excellent field for the study of urban commodification in the financially dependent periphery of the Eurozone. This is due to the combination of two major factors. On the one hand, Lisbon is the capital and largest city of a semiperipheral country that joined the European Economic Community (EEC) in 1986 and therefore has been a member of the European Union (EU) since 1993. Furthermore, Portugal adopted the euro as soon as it came into circulation in 2002, and experienced a profound process of dependent financialisation and alleged modernisation until the crisis of 2008. However, Portugal is one of the European countries that suffered the impact of the latter with most intensity, and austerity has been imposed there with special harshness. That makes Portugal an interesting case for the study of neoliberal structural adjustment and its socioeconomic effects. On the other hand, Lisbon's historic centre is currently experiencing a deep and rapid transformation that, fuelled by global real estate investment and a remarkable tourism boom, started and has developed while the Southern European country - along with Spain and Greece - has been subject to austerity under the increasing burden of sovereign debt.

\section{METHODOLOGY}

The urban transformation and commodification of Lisbon's historic centre is an ongoing process taking place in the context of the crisis of the southern periphery of the Eurozone. 
Therefore, the case-study methodology has been chosen to guide its analysis, since it allows the examination of ' $[. .$.$] an existing, real-life situation in all its complexity, exploring it as close to$ the people concerned as possible, describing the situation in as much detail as possible, and finally explaining the findings in a clear and comprehensible way.' [1].

Quantitative and qualitative analyses are combined in this research. The former is based on official statistical data from Eurostat, Instituto Nacional de Estatística (INE) [Statistics Portugal], Ministério da Administração Interna [Ministry of Internal Administration], and the Organisation for Economic Co-operation and Development (OECD). Meanwhile, the qualitative analysis involves direct observation and the conduction in Lisbon, between June and September 2016, of 12 structured interviews with the stakeholders listed in Table 1, who were asked 14 common questions. The interviews were held in Portuguese and the answers have been translated into English when quoted.

\section{THEORETICAL FRAMEWORK}

\subsection{Uneven development}

Uneven development is the consequence of capital migrating towards those locations offering greater potential profits [2]. According to Smith [3], '[...] uneven development is the systematic geographical expression of the contradictions inherent in the very constitution and structure of capital.' Additionally, he argues that '[...] uneven development should be conceived as a quite specific process that is both unique to capitalist societies and rooted directly in the fundamental social relations of this mode of production' [4]. However, Smith remarks that it is not at the global but at the local scale that uneven development achieves greatest completeness, guaranteed by the cycle of development, underdevelopment, and redevelopment of urban areas by real estate capital. Building upon his work, Brenner and Theodore [5] argue that ' $[\mathrm{u}]$ neven development is endemic to capitalism as an historical-geographical

Table 1: Interviewed stakeholders.

\begin{tabular}{lll}
\hline Public Sector & Private Sector & Civic Sector \\
\hline $\begin{array}{l}\text { André Moura } \\
\text { Lisbon Tourism Observatory } \\
\text { (Coordinator) }\end{array}$ & $\begin{array}{l}\text { Catarina Lopes } \\
\text { EastBanc Portugal } \\
\text { (General manager) }\end{array}$ & $\begin{array}{l}\text { Inês Andrade } \\
\text { Renovate Mouraria } \\
\text { (President) }\end{array}$ \\
$\begin{array}{l}\text { Miguel Coelho } \\
\text { Parish Council of Santa }\end{array}$ & Ernesto Portugal & Rita Silva \\
Maria Maior (President) & (Marketing manager) & Habita \\
Paula Marques & Nuno Martins & Leonor Duarte \\
Lisbon City Council & ERA Chiado/Lapa & Citizenship Academy \\
(Councillor for Housing and & (Partner) & (Member) \\
Local Development) & & \\
Pedro Miranda & Eduardo Miranda & Maria de Lurdes Pinheiro \\
Territorial Intervention & ALEP - Portuguese Local & APPA - Heritage and \\
Unit of the Historic Centre & Accommodation Association & Population Association of \\
(Senior technician) & (President) & Alfama (President) \\
\hline
\end{tabular}


system: it is a key expression of capital's relentless drive to mobilize particular territories and places as forces of production [...].'

According to mainstream economics, territories must compete for investment and consumption under globalisation, specialising in their so-called comparative advantage and improving their attractiveness. As global capital is unleashed, the same territories that are instigated to reduce welfare under austerity offer tax breaks and other benefits to attract the former, while they become increasingly vulnerable to and dependent on its volatile speculative behaviour. Lack of control over capital movements exposes the economies at different scales to inflows and outflows of financial assets that disappear as fast and easily as they appear, triggering or deepening crises [6-8].

\subsection{The rent gap theory}

The metropolitan core-periphery duality is the most remarkable local manifestation of uneven development. As suburbanisation encourages capital accumulation in the periphery and disinvestment in the inner city, it creates the conditions for eventually reinvesting in the latter through the generation of a rent gap [9]. According to Smith [10], gentrification has been explained by neoclassical economics as a consequence of changes in consumer preferences and choices. However, he argues that this fails to explain the simultaneous dynamics in different regions after the fifties and limits its analysis to the consumers while ignoring the role of the producers. When the latter are taken into account, he argues, profit becomes more relevant than consumer choice for grasping gentrification. Indeed, Smith associates gentrification with capital accumulation and uneven development, connecting it to broader restructuring processes in the economic, political, and geographic dimensions. $\mathrm{He}$ argues that urban economic cycles are linked to national and global economic dynamics.

According to Smith's rent gap theory, gentrification starts when the difference between actual and potential rents is wide enough to encourage investment:

The rent gap is the disparity between the potential ground rent level and the actual ground rent capitalized under the present land use [...]. The rent gap is produced primarily by capital devalorization (which diminishes the proportion of the ground rent able to be capitalized) and also by continued urban development and expansion (which has historically raised the potential ground rent level in the inner city). [...] As filtering and neighborhood decline proceed, the rent gap widens. Gentrification occurs when the gap is sufficiently wide that developers can purchase structures cheaply, can pay the builder's costs and profit for rehabilitation, can pay interest on mortgage and construction loans, and can then sell the end product for a sale price that leaves a satisfactory return to the developer. [11]

Focusing on investment and disinvestment, devalorisation and revalorisation, Smith provides a framework for understanding the logics of central urban decline in terms of the decisions made by private and public actors and real estate market forces. According to him, disinvestment encourages further disinvestment. House values and ground rents decrease, sale prices fall, investors and creditors move to more profitable and safer neighbourhoods, and eventually violence emerges. Temporarily, subdivision of degraded properties may maintain profits until buildings are finally abandoned when their use is no longer profitable. Abandonment, he argues, is usually a neighbourhood-scale phenomenon. 


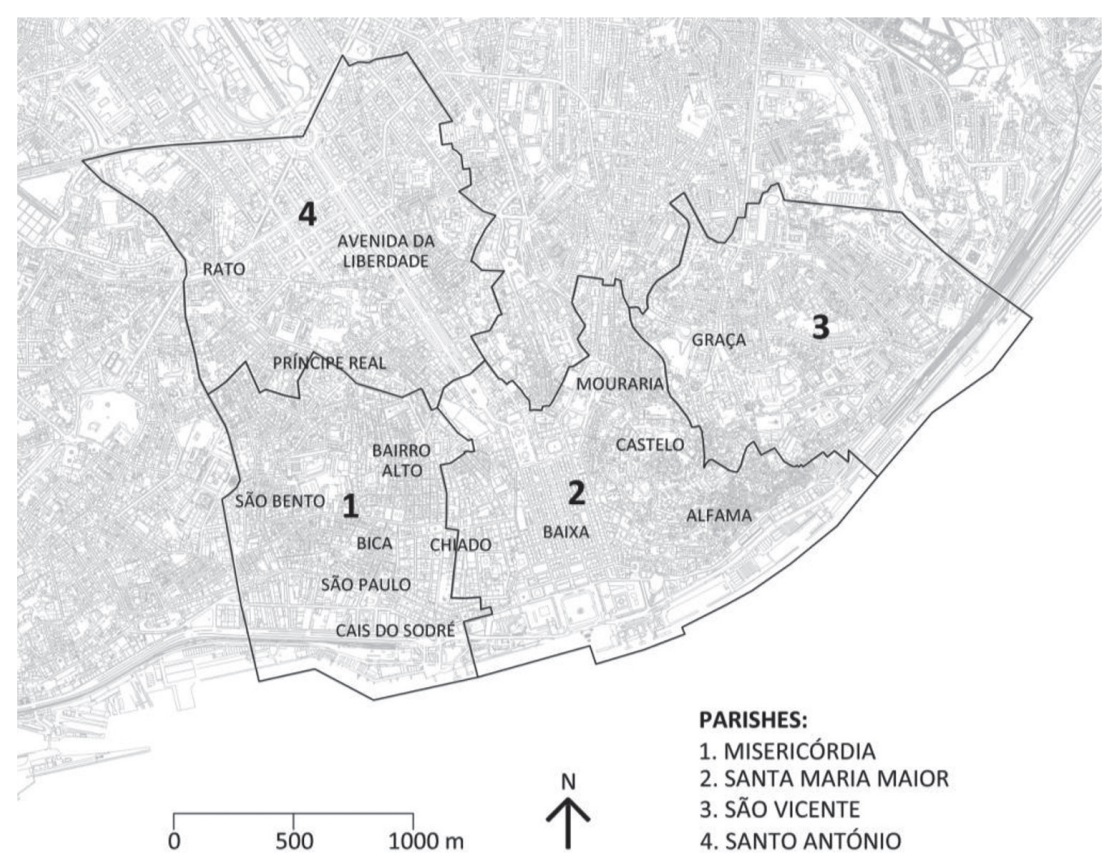

Figure 1: Parishes and neighbourhoods of Lisbon's historic centre. (Own work based on Câmara Municipal de Lisboa. Juntas de freguesia, Available at: http://www. cm-lisboa.pt/municipio/juntas-de-freguesia (Accessed 20 March 2017)).

\section{THE ONGOING TRANSFORMATION OF LISBON'S HISTORIC CENTRE}

\subsection{Abandonment and depopulation}

'The historic centre was empty, it was dead at night', said coordinator of Lisbon Tourism Observatory André Moura in his interview. Meanwhile, marketing manager of Habitat Invest Ernesto Portugal explained that ' $[\ldots]$ most buildings [in the historic centre] were abandoned and degraded a few years ago; they were collapsing with no maintenance at all.' In 2011, when the latest national census was elaborated, $32.4 \%$ of the conventional dwellings in the parish of Santa Maria Maior, 26.8\% of those in Misericórdia, 23\% of those in Santo António, and $20 \%$ of those in São Vicente were empty (Fig. 1) [12].

The evolution of the number of registered voters between January 2002 and December 2015 confirms the demographic decline of the municipality of Lisbon and evidences a more significant population loss in the historic centre, paralleled by an opposite trend in Lisbon Metropolitan Area (AML) as a whole. The number of registered voters decreased during that period by $27.3 \%$ in the historic centre and by $11.5 \%$ in the municipality, while it grew $7.5 \%$ in the AML. Within the historic centre, the decline was greater in Santa Maria Maior and Misericórdia, which lost $32.8 \%$ and $30.3 \%$ of their registered voters respectively between 2002 and 2015. Meanwhile, São Vicente and Santo António lost 23.6\% and 22.1\%, respectively [13].

The rent controls that were put in place during the dictatorship and materialised in the payment of very low rents by traditional tenants until the legal reform of 2012 are often blamed 
of having triggered the abandonment of Lisbon's historic centre. They are generally assumed to have prevented landlords from maintaining their properties, leading to the deterioration of the housing stock. However, president of APPA Maria de Lurdes Pinheiro argued in her interview that ' $[\ldots]$ tenants were paying very low rents, but it was them taking care of the houses. If buildings were not collapsing it was because of them; landlords were doing nothing but speculate. At most, they were maintaining the façades.' Furthermore, she highlighted that 'rents were frozen for old tenants but landlords were still charging as much as they wanted for the new contracts [...].' According to president of Habita association Rita Silva, the abandonment of the historic centre since the eighties was not triggered by the rent controls but by the 'speculative' model of suburban expansion. Meanwhile, president of ALEP Eduardo Miranda pointed at the small average sizes and typologies of the historic centre's housing stock as a significant factor behind its demographic decline. Furthermore, he indicated that in old neighbourhoods like Alfama moving out '[...] was part of the story of family success: $m y$ son studied, got married, and lives in the suburbs.'

\subsection{Austerity and impoverishment}

The European core-periphery gap and the financial and political dependency of Portugal and other southern countries have deepened after 2008. Rodrigues and Reis [14] suggest that the causes of the European crisis are found in '[...] the macroeconomic imbalances generated by the Euro and the operation of financial capital, as well as the irredeemable interdependencies between public, private, and foreign debts.' For Fujita [15], the crisis '[...] has revealed the fundamental problems of the EU: democracy, regional gap in income and growth, and internal social inequality.' The southern members of the Eurozone, by engaging with global finance and opening up as net borrowers to international capital flows, represent what Lapavitsas and Powell define as 'subordinate financialisation' [16].

In the southern periphery of the Eurozone, the imposition of austerity has been supported by an official narrative pointing at an allegedly excessive public debt that was not a reality in Portugal before 2008. Indeed, the Portuguese general government gross debt had expanded since 2000 but represented $71.7 \%$ of its GDP in 2008. That year, Germany's general government gross debt was of $65.1 \%$ of its GDP and the Eurozone-19 average was of $68.6 \%$. Nevertheless, the Portuguese general government gross debt would expand significantly after 2008 and reached $130.6 \%$ of the GDP in 2014. That year, Germany's debt was of $74.9 \%$ and the Eurozone-19 average was of $92 \%$ [17]. The official statistical data evidence that, as suggested by Blyth [18], excessive public indebtedness is not cause but consequence of the crisis of the southern European periphery.

Austerity has had a severe impact over the average income and purchasing power of the Portuguese, impoverishing the poor and proletarianising the middle class. According to Serra $[19]$, ' $[\ldots]$ the middle class is disappearing, giving way to a minority of very rich and a majority of poor citizens, as is happening in the other 'PIGS' countries [...].' Indeed, the unemployment rate doubled in Portugal from $8.8 \%$ in 2008 to $16.4 \%$ in 2013. Despite having dropped to $11.2 \%$ by 2016 , it has remained above the Eurozone-19 average during the whole period [20]. In the AML it reached $18.5 \%$ in 2013 [21].

As a semiperipheral economy, Portugal merges characteristics of the core and of the periphery, with modern financial system and consumption habits coexisting with a structurally backward economy. The abundant foreign credit that was received by the Portuguese private sector since the mid-nineties was not used to improve the structural conditions of the 
country's economy but channelled by the privatised banking system towards the non-tradable sectors, less subject to international competition. As it boosted public investment in infrastructure, promoted public-private partnerships, and encouraged market-based homeownership, the Portuguese State created the conditions for credit to flow towards the construction and real estate sectors, fuelled suburban expansion, and stimulated the indebtedness of firms and families until the crisis of 2008 [22, 23]. It is against this socioeconomic background that the ongoing transformation of Lisbon's historic centre and the sale of its housing stock at rising prices on the global real estate market are taking place.

According to president of the Parish Council of Santa Maria Maior Miguel Coelho, 'many saw their income decrease brutally due to the government's cuts on benefits, pensions, and subsidies. Purchasing power dropped, people lost their jobs, the middle class lost resources...' Meanwhile, member of Citizenship Academy Leonor Duarte explained that the general income loss during the crisis pushed many out of their homes and put more pressure on Lisbon's social housing stock. Partner at ERA Chiado/Lapa Nuno Martins said that 'the impact [of the crisis] was brutal in 2009; the real estate market fell due to the international crisis and the credit crunch after a period of irresponsible lending behaviour.' According to marketing manager of Habitat Invest Ernesto Portugal, 'the real estate market is recovering now, but the Portuguese economy is still anemic. This is evidenced by the lack of Portuguese customers. We had to turn to those foreign markets where there is money, demand, and investment.' His statement was shared by general manager of EastBanc Portugal Catarina Lopes, who added that ' $[\ldots]$ it makes no sense for us investors to focus on the Portuguese market because the economy is still very depressed.'

\subsection{An investor-friendly legal framework}

\subsubsection{The new urban lease law}

Introduced in 2012 as mandated by the Memorandum of Understanding [24] signed in 2011 between the Portuguese government and the Troika, the amendments to the Novo Regime do Arrendamento Urbano (NRAU) [new urban lease regime] were intended to stimulate urban regeneration by facilitating the termination of old contracts, removing the rent controls, and speeding up the eviction process. However, this new legislation unprotected the tenants, strengthened the landlords, and enabled rents to rise above the financial capacity of many of the former in a context of retreating State, general impoverishment, and expanded demand for leased dwellings under austerity [9]. Despite the elderly and the very vulnerable remaining relatively protected after 2012, and despite recent initiatives seeking to preserve the historic shops and extending the transition period for old contracts to adapt to the new regime, the liberalisation of the rental market in times of crisis, austerity, and tourism boom has triggered the commodification of Lisbon's historic centre.

In her interview, Maria de Lurdes Pinheiro defined the new urban lease regime as "the eviction law.' Catarina Lopes highlighted the fact of the legal reform of 2012 having '[...] unlocked lots of spaces that were closed and allowed new things to be opened and investors to invest.' Rita Silva associated this policy with the Troika's plan to stimulate real estate investment and profitability. She argued that, after the collapse of the model of suburban development and the stop of the credit flow towards the Portuguese middle class in 2008, real estate investors turned the attention towards Lisbon's historic centre. This ' $[\ldots]$ offered high profitability opportunities based on luxury regeneration and high-end developments. But since most of the residents in the historic centre were tenants, it became necessary to 
change the lease law to rapidly and easily evict them [...]', Silva explained in her interview.

André Moura argued that the new urban lease regime '[...] had a great impact on the historic centre. There was a shift from being able to do nothing to being able to do anything. Tourism has been crucial for urban regeneration and this reform was fundamental to stimulate it.' However, according to Leonor Duarte, 'residents are being evicted in the historic centre. Buildings are sold and the new owners only need to say that they'll refurbish them even if it's false, because nobody checks - and then they can terminate the contracts.' Eduardo Miranda indicated that the most important effect of that policy was to allow the renegotiation of old rents. In 2012, he argued, all landlords who could start the rent-update process did so, even if they had no specific plans for the property, '[...] because otherwise they couldn't sell it, they couldn't lease it, they could do nothing with it.'

\subsubsection{The non-regular resident tax regime}

The non-regular resident tax regime is another instrument stimulating the commodification of Lisbon's historic centre and the refurbishment of its housing stock. In September 2009, this policy was implemented by the Portuguese government to attract high-income professionals and pensioners from other countries in the EU. Under this scheme, the former benefit from a reduced flat personal income tax rate of $20 \%$ as long as they spend more than 183 days a year in Portugal or they have a dwelling in the country and the intention to occupy it as habitual residence [25]. Since 2013, any pension income generated outside Portugal is totally tax exempt - even when not taxed in the country of origin.

JLL Research [26] indicates that '[t]he competitiveness of the Portuguese regime compared with similar regimes in other countries has resulted in important investments in the national real estate sector.' According to this source, '[s]everal foreign citizens, mainly French, have purchased a house in Portugal, attracted by the advantages of Non-Habitual Residents Benefits and also by the quality of life that Portugal offers.' According to Eduardo Miranda, the non-regular resident tax regime ' $[\ldots]$ is the core, the engine of urban regeneration in Lisbon. It encourages Belgians, Scandinavians... and mostly French to purchase property in Portugal. Some 25 thousand French are estimated to have come to live here in the last years.' He highlighted that those boost the regeneration of the historic centre and dynamise its real estate sector, but remarked that 'it's very difficult for a Portuguese to find properties to buy there now because they're all being sold to foreigners.'

Demand for real estate property in Lisbon's historic centre expands and housing prices rise in that territory and in its surroundings due to the incorporation to the market of a large number of citizens of wealthier countries who not only have greater financial capacity but also enjoy significant tax breaks. In 2016, the monthly minimum wage was 618.33 euro in Portugal and 1,466.62 in France [27] - the EU country supplying the vast majority of purchasers of real estate in Lisbon's historic centre under the non-regular resident tax regime. In 2014, the median hourly earning was 5.12 euro in Portugal - far from the Eurozone-19 average of 14.08 - and 14.94 in France [28]. The average pension wealth in US dollars is 166 thousand for men and 191 thousand for women in Portugal, while it amounts to 435 and 522 thousand, respectively, in France [29].

\subsubsection{The Golden Visa programme}

Although quantitatively less significant than the non-regular resident tax regime, since 2012 the Golden Visa programme has contributed to the commodification of Lisbon's historic cen- 
tre. It encourages non-European citizens to invest at least 500 thousand euro in Portugal generally in real estate property - by offering them the residence permit. In case of acquisition and refurbishment of properties that are more than 30 years old or are located in designated urban regeneration areas, an investment of 350 thousand euro is enough for being eligible for a Golden Visa [30]. Asked about the impact of this scheme and the non-regular resident tax regime on Habitat Invest's activity, Ernesto Portugal said that both policies and the removal of rent controls have boosted foreign investment and encouraged urban regeneration. 'A large part of our customers are Golden Visa holders. The non-regular resident tax regime has had more remarkable impacts on the French and Scandinavian markets, but I think it still has a lot to deliver', he said.

According to Nuno Martins, the Golden Visa programme has been especially useful for attracting Chinese investment, but the non-regular resident tax regime is more significant nowadays: 'Three or four years ago, the Golden Visa was very important. Then, due to some irregularities that were identified, it dropped while fiscal incentives skyrocketed. Since the beginning of 2016, the Golden Visa programme has grown again.' While recognising that the Golden Visa programme absorbs housing stock and increases prices, Catarina Lopes stated a more favourable opinion on the non-regular resident tax regime. Unlike the former, which '[...] attracts people with half a million euro - now they only need 350 thousand - who arrive here and then don't show up again', the latter '[...] brings people with higher educational level, many entrepreneurs who must stay here at least $50 \%$ of the time and therefore will be doing something here. And it's very-high-income people.'

\subsection{The rise of housing prices}

President of APPA Maria de Lurdes Pinheiro argued that only the wealthy can afford an apartment in the historic neighbourhood of Alfama since the liberalisation of the rental market in 2012. During his interview, Miguel Coelho expressed serious concern about gentrification in the parish of Santa Maria Maior: 'Many of the residents are not reaching the benefits of this [urban] transformation. Urban regeneration is neither bringing more residents nor delivering more comfort to the existing ones. In fact, the opposite is happening: it's forcing them to leave.' Focusing on the historic neighbourhood of Mouraria, Inês Andrade explained that 'we lose population because people can't afford a house here anymore; prices have increased a lot.' According to Leonor Duarte, 'inhabitants are disappearing from the historic centre, which is planned to be left just for tourism and luxury housing. The population loss is constant and the attempts to secure the existing population are unsuccessful because the housing issue is not solved.'

Between 2012 and 2015, the number of housing sale/purchase contracts increased $22.3 \%$ in Portugal and $105.9 \%$ in Lisbon [31]. The average value of the traded dwellings was $26 \%$ higher in 2015 than in 2011 in Lisbon and 18.2\% higher in Portugal as a whole [32]. Urban regeneration explains the new dynamism of the Portuguese real estate sector, '[...] owing to greater demand from international investors, fuelled by the potential of tourism and the international public's growing interest in high and medium-high quality housing products.' [33]. In Lisbon's historic centre, the average housing price increased $22.3 \%$ only in 2015 . A total of 2,199 sales worth 709 million euro were registered that year in that urban area $-11 \%$ and $37 \%$ more, respectively, than in 2014 [34]. According to the consulting firm Cushman \& Wakefield, the average asking price in Lisbon was close to 3,000 euro per square metre by the end of 2015. 
Meanwhile, housing supply for permanent residence has dropped significantly in Lisbon's historic centre as a corollary of the proliferation of tourist apartments and the multiplication of global investors attracted by the profitability of urban regeneration. The incapacity for most locals to afford housing in that area expands demand and pushes prices up in the periphery as well. In his interview, Miguel Coelho expressed concern about the excessive concentration of tourist apartments in the historic centre and the increase of real estate prices: 'Three years ago, when I was elected [president of the Parish Council of Santa Maria Maior], a T1 in Alfama costed between 80 and 150 euro a month depending on the condition of the apartment. Now it costs 1,000, maybe 1,500 euro.' Ernesto Portugal indicated that three years ago Habitat Invest was selling apartments for 3,000 euro per square metre and now they are doing so above 6,000. 'There has been a general sustained growth and I believe this trend will continue in the next years, because we're still far from the values of other European capitals', he argued. For Eduardo Miranda, any improvement of the housing conditions in those areas where rents had been kept very low triggers gentrification: 'Any small improvement I do, I already want 50 or 100 more euro of rent, and that population [with controlled rents] is left out of the market.' And he added: 'Even without the foreign market and the tourists, those rents were unsustainable; they would rise to 350 or 400 euro. Students have paid 250 euro for years and pay 300 for a room in good condition.'

Senior technician at Lisbon City Council Pedro Miranda mentioned rent increases as 'the dark side of regeneration', since locals cannot compete with tourists for the refurbished properties: 'If you're paying 200 or 300 euro and the rent suddenly rises to 1,000 - if the landlord wants to lease the apartment on a monthly basis at all - then how can you afford that?' Nuno Martins indicated that real estate values have become really high in some areas of the historic centre. In the most expensive ones, he explained that prices are close to 10,000 euro per refurbished square metre. 'That's very high for the national reality, it's brutal, but there's a small percentage of the population with lots of capital who can reach that', he argued, and highlighted the existence of a 'growing disequilibrium' between high demand and low supply in the real estate market of Lisbon's historic centre. He indicated that, in little more than one year, the price of the refurbished square metre increased from 2,500-3,000 to 3,000-4,000 euro in the area of operation of ERA Chiado/Lapa between Infante Santo avenue, Áurea street and Príncipe Real - with the exception of the premium areas of Chiado and Lapa. 'This has obviously made housing less affordable in Lisbon; prices were 30\% lower just one year ago', he concluded.

According to the coordinator of Lisbon Tourism Observatory, 'prices have rosen, of course, but that's the market law: if something becomes more attractive it automatically becomes more expensive - unless there are public policies of price control, which may work during a given period.' Additionally, he argued that some years ago '[...] people didn't want to come [to the historic centre] because it was old, it wasn't interesting, it wasn't appealing. Now they want to because it's beautiful and appealing, but what's beautiful is more expensive, that's the current model.' Meanwhile, the marketing manager of Habitat Invest interpreted the increase of real estate values and rents as a positive phenomenon stimulating a market that was stagnant. While he recognised that 'access to housing may be more difficult' now, he also highlighted that the former supply of degraded dwellings in derelict buildings has been replaced by a high-quality stock of refurbished apartments. For the president of ALEP, Lisbon's real estate prices are not compatible with the national market but still have a margin to increase in the international one. In contrast, the general manager of EastBanc Portugal suggested that Lisbon's real estate market is 'overpriced.' 
According to the President of Habita association, 'urban regeneration is good, but this regeneration is expelling the inhabitants because it's not for the people who live here.' Councillor for Housing and Local Development Paula Marques argued that 'it's a fact that urban regeneration has created a disequilibrium when it comes to social mixture. We shouldn't demonise tourism because it generates economic activity and employment, but the imbalances that it generates must be addressed.' She added that 'a city needs to be inhabited by a diverse population. Tourism and tourists are welcome - we're also visitors elsewhere. Mixture is welcome - Lisbon has always been inhabited by very diverse people.' However, she highlighted that ' $[\ldots]$ we need to address the issue of real estate speculation that is linked to the Golden Visa programme and to foreign investment that is not focused on residence but on speculation.'

\section{CONCLUSION}

The financial crisis and the imposition of austerity crushed the purchasing power of the Portuguese society, impoverishing the poor and proletarianising the middle class. It is against this socioeconomic background and against the financial dependency of the Portuguese economy that the ongoing transformation of Lisbon's historic centre and the sale of its housing stock at rising prices on the global real estate market are taking place. Being Portugal peripheral within the EU and the Eurozone and semiperipheral within the world-economy, the gap between actual and potential real estate rents in Lisbon's historic centre owes much to the gap between the domestic and the external markets' purchasing powers. Skilled professionals and pensioners from core countries find the Portuguese housing prices very affordable - still despite their remarkable increase pushed by their own demand and by the proliferation of tourist apartments - and are also offered fiscal incentives to purchase real estate property in the country. Meanwhile, the local community - denied credit and reduced its income after 2008 - is excluded from housing access in Lisbon's historic centre and, as a corollary, from its surrounding neighbourhoods as well.

As it strangled the domestic economy and eroded the average purchasing power, the combination of crisis and austerity in the Portuguese dependent and structurally backward economy encouraged the sale of assets to global investors - including the housing stock of Lisbon's historic centre. This has materialised in the dramatic rise of housing rents and prices, in the shortage of dwellings for residential lease, and in the displacement of population from that territory. The ongoing gentrification and commodification of Lisbon's historic centre increasingly monopolised by tourists and wealthy investors - is a product of the interaction of crisis, austerity, and dependency with mass tourism and an investor-friendly legal framework implemented in the wake of the crisis of 2008. As they stimulate demand on external markets with greater purchasing power, the new urban lease law, the non-regular resident tax regime, and the Golden Visa programme among other policies stimulate the rise of housing prices above the financial capacity of the local population - despite their success in boosting the refurbishment of derelict properties.

However, grassroots movements have emerged in Lisbon that advocate affordable housing and the right to the city, demand policy changes, engage in the public debate, and participate in the elaboration of alternatives against the commodification of the city. It remains to be seen how much influence these initiatives and others that may emerge will have on the actual urban policies of the years to come. 


\section{ACKNOWLEDGEMENTS}

We are very grateful to the 12 interview participants for having shared their time and perspectives.

\section{REFERENCES}

[1] Kyburz-Graber, R., Does case-study methodology lack rigour? The need for quality criteria for sound case-study research, as illustrated by a recent case in secondary and higher education. Environmental Education Research, 10(1), pp. 53-65, 2004. https://doi.org/10.1080/1350462032000173706

[2] Harvey, D., Rebel cities: from the right to the city to the urban revolution, Verso: London, 2012.

[3] Smith, N., Uneven development: nature, capital, and the production of space, Verso: London, p. 4, 2010.

[4] Smith, N., The new urban frontier: gentrification and the revanchist city, Routledge: New York City, p. 74, 1996.

[5] Brenner, N. \& Theodore, N., Cities and the geographies of actually existing neoliberalism. Antipode, 34(3), p. 355, 2002.

https://doi.org/10.1111/1467-8330.00246

[6] Brenner, N., Peck, J., \& Theodore, N., Urbanismo neoliberal. La ciudad y el imperio de los mercados. El mercado contra la ciudad. Sobre globalización, gentrificación y políticas urbanas, ed. Observatorio Metropolitano de Madrid, Traficantes de Sueños: Madrid, pp. 211-243, 2015.

[7] Harris, N., Introduction. Cities and structural adjustment, eds. N. Harris \& I. Fabricius, UCL Press: London, pp. 1-12, 1996.

[8] Sassen, S., Cities in a world economy, Pine Forge Press: Thousand Oaks, CA, 2000.

[9] Mendes, L., Gentrificação e políticas de reabilitação urbana em Portugal: uma análise crítica à luz da tese rent gap de Neil Smith. Cadernos Metrópole, 16(32), pp. 487-511, 2014.

https://doi.org/10.1590/2236-9996.2014-3209

[10] Smith, N., The new urban frontier: gentrification and the revanchist city, Routledge: New York City, 1996.

[11] Smith, N., The new urban frontier: gentrification and the revanchist city, Routledge: New York City, p. 65, 1996.

[12] Instituto Nacional de Estatística (INE). Proporção de alojamentos familiares clássicos vagos (\%) por localização geográfica, available at: https://www.ine.pt/xportal/ xmain?xpid=INE\&xpgid=ine_indicadores\&indOcorrCod=0006987\&contexto=bd\&se $1 \mathrm{Tab}=\mathrm{tab} 2$. (Accessed 08 July 2016).

[13] Ministério da Administração Interna. Recenseamento eleitoral, available at: http:// www.sg.mai.gov.pt/AdministracaoEleitoral/RecenseamentoEleitoral/ResultadosRecenseamento/Paginas/default.aspx. (Accessed 20 March 2016).

[14] Rodrigues, J. \& Reis, J., The asymmetries of European integration and the crisis of capitalism in Portugal. Competition and Change, 16(3), p. 192, 2012.

[15] Fujita, K., Introduction. Cities and crisis: new critical urban theory, ed. K. Fujita, Sage Studies in International Sociology: London, pp. 19-20, 2013.

[16] Rodrigues, J., Santos, A.C. \& Teles, N., A financeirização do capitalismo em Portugal, Conjuntura Actual Editora: Coimbra, pp. 36-37, 2016. 
[17] Eurostat. General government gross debt, available at: http://ec.europa.eu/eurostat/tgm/ table.do?tab=table \&init $=1 \&$ language $=$ en $\&$ pcode $=$ tsdde410\&plugin $=1$. (Accessed 08 May 2017).

[18] Blyth, M., Austerity: the history of a dangerous idea, Oxford University Press: New York City, 2015.

[19] Serra, N., Debt and financialisation: the Portuguese example. Green European Journal, 7, p. 45, 2014.

[20] Eurostat. Unemployment rate - annual data, Available at: http://ec.europa.eu/eurostat/ tgm/table.do?tab=table\&init=1\&plugin=1\&pcode=tipsun20\&language=en. (Accessed 08 May 2017).

[21] Eurostat. Unemployment rates by sex, age and metropolitan regions, Available at: http:// ec.europa.eu/eurostat/web/products-datasets/-/met_lfu3rt. (Accessed 08 May 2017).

[22] Reis, J., Prefácio. A financeirização do capitalismo em Portugal, eds. J. Rodrigues, A. C. Santos, \& N. Teles, Conjuntura Actual Editora: Coimbra, pp. 11-22, 2016.

[23] Rodrigues, J., Santos, A.C. \& Teles, N., A financeirização do capitalismo em Portugal, Conjuntura Actual Editora: Coimbra, 2016.

[24] European Commission. Portugal: memorandum of understanding on specific economic policy conditionality, Available at: http://ec.europa.eu/economy_finance/eu_borrower/ mou/2011-05-18-mou-portugal_en.pdf. (Accessed 17 January 2017).

[25] Autoridade Tributária e Aduaneira. Personal income tax. Non-regular tax regime for non-regular residents, Available at: http://info.portaldasfinancas.gov.pt/NR/rdonlyres/ D0C80C76-3DA8-4B90-A1E4-FF53BD34EF95/0/IRS_RNH_EN.pdf. (Accessed 09 May 2017).

[26] JLL Research. Residential market: unrivaled dynamics pp. 11-12, 2017. Available at: http://www.jll.pt/portugal/en-gb/research/residential-market-unrivalled-dynamics. Accessed 28 January 2017).

[27] Eurostat. Monthly minimum wages - bi-annual data, available at: http://appsso.eurostat. ec.europa.eu/nui/show.do?dataset=earn_mw_cur\&lang=en. (Accessed 08 May 2017).

[28] Eurostat. Median hourly earnings, all employees (excluding apprentices) by sex. Available at: http://appsso.eurostat.ec.europa.eu/nui/show.do?dataset=earn_ses_ pub2s\&lang=en. (Accessed 08 May 2017).

[29] Organisation for Economic Co-operation and Development, Pensions at a glance 2013: $O E C D$ and G20 indicators, OECD Publishing: Paris, 2013.

[30] JLL Research. Residential market: unrivaled dynamics, Available at: http://www.jll.pt/ portugal/en-gb/research/residential-market-unrivalled-dynamics. (Accessed 28 January 2017).

[31] Instituto Nacional de Estatística (INE). Contratos de compra e venda (N..$^{\circ}$ ) de prédios por localização geográfica (NUTS - 2013) e tipo de prédio, anual, Available at: https:// www.ine.pt/xportal/xmain?xpid=INE\&xpgid=ine_indicadores\&indOcorrCod=000864 $9 \&$ contexto $=$ bd\&selTab=tab2. (Accessed 09 May 2017).

[32] Instituto Nacional de Estatística (INE). Valor médio dos prédios transaccionados $\left(€ /\right.$ N. $\left.^{\circ}\right)$ por localização geográfica (NUTS - 2013) e tipo de prédio, anual, Available at: https://www.ine.pt/xportal/xmain?xpid=INE\&xpgid=ine_indicadores\&indOcorrCo $\mathrm{d}=0008649 \&$ contexto $=$ bd\&selTab=tab2. (Accessed 09 May 2017).

[33] Cushman \& Wakefield. Marketbeat Portugal Spring 2016, Available at: http://www.cushmanwakefield.pt/en-gb/research-and-insight/2016/marketbeat-portugal-spring-2016/. (Accessed 16 August 2016).

[34] Confidencial Imobiliário. Imobiliário no Centro Histórico de Lisboa valoriza 22,3\% em 2015, Available at: http://www.confidencialimobiliario.com/?q=content/press-releaseimobiliario-no-centro-historico-de-lisboa-valoriza-223-em-2015. (Accessed 16 August 2016). 